\title{
Impact of Worker Remittances on Economic Growth of Pakistan: Analysis of Pakistan's Economy
}

\author{
M. Mobeen Shafqat \\ School of Management \& \\ Economics Beijing Institute \\ of Technology \\ Beijing, China \\ mobeen.shafqat@gmail.com
}

\author{
Ashfaq Ahmad \\ School of Management \& \\ Economics Beijing Institute \\ of Technology \\ Beijing, China \\ ashfaqahmad146@gmail.com
}

\author{
Sadia Bano \\ School of Management \\ \& Economics Beijing \\ Institute of Technology \\ Beijing, China \\ chir_ria06@yahoo.com
}

\begin{abstract}
We make this study for the purpose of getting logical answer about a very famous matter regarding contribution of worker's remittance in the growth of the economy of Pakistan. We also include different variables to evaluate the exact effect of foreign exchange earnings in economic growth of Pakistan by using time series data for the duration of 1991 to 2010 . Here we applied OLS multiple regressions model and also check the assumptions of OLS by different diagnostic tests. The empirical and quantitative results describe that foreign remittance are the famous mean of economic growth and have significant positive relationship with each other. The productive use of this paper can help the economy of Pakistan to maintain and improve the economic growth by investing this money into different long term and short term projects. Pakistan's Government should provide different incentives and lower down the cost of transactions to attract the overseas Pakistani emigrants that sent money through unofficial ways.
\end{abstract}

Key words: Foreign remittances, Economic growth, Financial Development, Economy of Pakistan

\section{Introduction}

The promotion of economic growth in recipient countries is widely effected by the workers' remittances, so it is very famous area for research. Particularly, reasonable research in this field can provide productive ideas to policy makers for taking best decisions regarding management of these flows in the way that it will give productive output in terms of investment .These remittances are the best mean of income in terms of foreign exchange from developed countries to underdeveloped countries. You can say, in the favor of remittances that they have positive impact on balance of payment, decreased external debt and other economic benefits.

Although, there is another view that foreign exchange earnings have inverse relationship with economic growth. Just analyze, when remittances are sent by the Pakistan's working abroad to their home country Pakistan that is developing country 
resulting in a trend that is highlighted, Includes less participation of work force and diminished trend of work exertion from the labor force. This inverse relationship between remittances and economic growth was originated by Chami, fullenkamp and Jahjah (2003), Panel data was used by them covering over 113 countries. In topical decades there was a massive sum of foreign exchange earnings which was sent by the workers to Pakistan. In least developed country like Pakistan foreign remittances results in low level of joblessness, greater than before purchasing of familial as well as imported goods. Enhanced purchasing of local products impacted improved industrial production and also resulting in encouraging impact on balance of payment representing greater yield and economic growth. A lot of papers revealed that many of overseas remittances were going to be used in utilization. Instead of this, reasonable indications showed that prominent part of foreign remittances was utilized in valuable investment.

Many researchers squabble the suggestion that although in case of remittances, if we entirely depleted them on consumption of domestic products and imported commodities it ought to be beneficial for the recipient countries. Earlier studies did not evaluated impact of remittances properly on economic growth in Pakistan. Most of the studies (As discussed) in next segment revealed the relationship of worker remittances and growth of the economy in an expressive way. Methodical framework was not utilized precisely by them in previous studies. Research shows that in the beginning of studies there was only a faint view regarding effect of foreign exchange earnings, especially on economic growth particularly in Pakistan. Now in current literature research work in the area of remittances stand upon the data which is collected by the survey in an exacting point of time on one point.

In current paper, a logical framework is channeled to measure the impacts of overseas remittances on economic growth. For this purpose, we used currently available data of time series for the duration of 1972-73 till 2002-03. Here, the question arises that "Do worker remittances promote economic growth in Pakistan?" Our hypothesis regarding the research is that as we studied role of worker remittances in local investment or in consumption, there should be its contribution in growth of the economy of Pakistan in a straight or indirect way. The portion of paper's configuration that is left behind is as follows: Segment 2 consists on literature review, Segment3 illustrates progress in worker remittances and growth in the economy for past 30 years, Segment 4 elaborates the facts and presents logical framework, whereas the Segment 5 talk about the empirical results and Segment 6 describes the conclusion.

\section{Literature Review}

In literature different studies that were employed to show the contribution of worker remittances on economic growth had provided mixed results. Some of the studies favoring that worker remittance have positive relationship with economic growth, some of them favoring negative relationship and some of them favoring neutral or no relationship. Faini (2002) claimed that remittances had a positive influence on economic growth by regressing remittances and other predictors on economic growth of selected countries. He suggested that this positive relationship of worker remittances and economic growth facilitates in improving productive infrastructure, reducing uncertainty and accumulation of industrious assets to households. Chami, Fullenkamp, and Jajah (2003) claimed that remittances had an inverse relationship with growth by taking a sample of 113 countries. They had provided justification of inverse relationship 
between remittances and growth as a moral hazard. Moral hazard inevitable that dependent of immigrants in developing countries only rely upon the income of immigrants in foreign countries. So, fundamentally they concluded that the families that received the remittances income were not working in their home countries and a huge shortage of labor will adversely effect economic growth of a particular country.

Giuliano and Ruiz-Arranz (2005) had worked on data set of more than 100 developing countries from years 1975-2002 and found that remittances can enhance economic growth only in less financially developed countries. In the same year Iqbal and Sattar (2005) had employed multiple regression analysis on annual data of Pakistan from 1972-2003 and found a positive and significant relationship between worker remittance and economic growth of Pakistan. Rahman, Mustafa, Islam, and GuruGharana (2006) had employed co-integration and vector error correction models to investigate the main factors that contribute in the economic growth of Bangladesh. They founded that remittances can boost economic growth and create employment opportunities in short run. Jongwanich (2007) had investigate the impact of worker remittances on economic growth and poverty reeducation in 17 countries of Asia and Pacific region. He employed Generalized Method of Moments (GMM) regression technique on the panel data of 17 countries from 1993-2003. He found that there is direct and marginal impact of remittance on economic growth of Asia and Pacific countries.

Pradhan, Upadhyay, and Upadhyaya (2008) that investigates the relationship between remittances and economic growth through panel data from 1980-2004 of 39 major developing countries. Both panel data techniques fixed effects and random effects are employed in order to confirm the contribution of remittances on economic growth and rejected random effects model on the basis of statistical test (Hausman's Specification test).They concluded that Remittances has a direct relationship with economic growth.Gapen, Barajas, Chami, Montiel, and Fullenkamp (2009) had explored the question "do workers remittances promote economic growth?" by using panel data of 84 countries from 1970-2004. They concluded that there would be an inverse relationship between remittances and economic growth when remittances is measured appropriate and economic growth questions are properly defined. In the same year Karagoz (2009) had worked on worker remittances and economic growth by using annual data of Turkey from 1970-2005. He had employed Johansen co-integration test to investigate the long run relationship between worker remittances and economic growth. He found an inverse but significant relationship between remittances and economic growth.Siddique, Selvanathan, and Selvanathan (2010) had investigates the relationship between economic growth and worker remittances in three Asian countries India, Sri Lanka and Bangladesh by using time series annual data from 1975-2006. They had employed co-integration and Granger causality test to investigate the long run and short run relationship. They concluded that remittances had direct relationship in case of Bangladesh, no relationship was found between remittances and economic growth while in Sri Lanka worker remittances and economic growth had two-way relationship.

Most recently, Nsiah and Fayissa (2011) had investigate the relationship between economic growth and remittances through panel data of 64 different countries of African, Asian, and Latin American-Caribbean from 1987-2007. They had employed panel unit root and panel co-integration tests to investigate the exact relationship 
between remittances and economic growth. They found that there is positive relationship between remittances and economic growth throughout the whole group.

\section{Data and Methodology}

In this study data for all variables is collected from the publications of World Bank data set "World Development Indicators" and State Bank of Pakistan. Data set covers most recent year's annual data from 1991-2010. Gujarati (2003) recommended that standard tests of stationary are mostly applicable for large sample size and as the sample size in the current study is not so huge that is way researcher have not employed any test for stationary. In order to investigate the impact of worker remittances on economic growth of Pakistan multiple regression analysis are employed. Some studies had been employed multiple regression analysis to investigate the impact of worker remittances on economic growth (Ang, 2007; Chami, Fullenkamp, \& Jajah, 2003; Iqbal \& Sattar, 2005; Singh, Haacker, Lee, \& Le Goff, 2011). So, the final Ordinary Least Square (OLS) models of this study are as follows;

GROWTH $_{\mathrm{i}}=\alpha_{0}+\alpha_{1}$ WORREM $_{\mathrm{i}}+\alpha_{2}$ FINDEV $_{\mathrm{i}}+\alpha_{3}$ CONSUM $_{\mathrm{i}}+\alpha_{4}$ SAVING $_{\mathrm{i}}+$ $\alpha_{5} \mathrm{CABAL}_{\mathrm{i}}+\varepsilon_{\mathrm{I}}$

GROWTH $_{\mathrm{i}}=\alpha_{0}+\alpha_{1}$ FINDEV $_{\mathrm{i}}+\alpha_{2}$ CONSUM $_{\mathrm{i}}+\alpha_{3} \mathrm{SAVING}_{\mathrm{i}}+\alpha_{4} \mathrm{CABAL}_{\mathrm{i}}+\varepsilon_{\mathrm{I}}$

Here;

GROWTHi $=$ Natural log of GDP per capita

WORREMi $=$ Worker Remittances Received to GDP

FINDEVi $=$ Ratio of money and quasi money (M2) to GDP

CONSUMi $=$ Household final consumption expenditure as a \% of GDP

SAVINGi $=$ Ratio of gross domestic savings to GDP

CABALi $=$ Current account BAL or balance as a percentage of GDP

$\boldsymbol{\alpha}_{0}$ and $\varepsilon_{\mathrm{I}}=$ Intercept term and error term in the model

Proxies and expected relationship of all the variables is provided in Table 1. Here, GROWTH $_{\mathrm{i}}$ is the dependent variable which is measured as natural log of Gross Domestic Product (GDP) per capita in US dollars. WORREM W $_{\mathrm{i}}$ is a stand for worker remittance is an independent variable and taken as ratio of worker remittances received to GDP. The worker remittances and economic growth has a positive relationship. While the remaining four variables are control variables which are add in the model to control for the effect of other most important variables that effects the economic growth. Including control variables in the model facilitates us to enhance the prediction power of variables or model and boost the precision of estimates(The Kellogg School of Management).

First control variable FINDEV $\mathrm{i}_{\mathrm{i}}$ stands for financial development and its proxy is ratio of Money and quasi money M2 to GDP. The expected relationship between financial development and economic grow this mixed some studies claimed positive relationship while other favor inverse relationship. The second control variable is household final consumption expenditure which represents by $\mathrm{CONSUM}_{\mathrm{i}}$ and this variable is calculated by ratio of Household final consumption expenditure to GDP. The 
theoretical relationship between house hold consumption expenditure and economic growth is positive.

The third control variable is gross domestic savings SAVING $_{i}$ Gross domestic savings which is measured by taking a ratio of gross domestic saving to GDP. The theoretical association of saving is direct as saving boost investment which ultimately result in higher economic growth while negative association is also reported in some situations. The last control variable is current account balance which is represented by $\mathrm{CABAL}_{\mathrm{i}}$ and this variable is also measured by taking ratio of current account balance to GDP. The expected linkage between current account balance and economic growth is either positive or negative in theory.

Table 1: Variables Descriptions and their Relationship

\begin{tabular}{|l|l|l|}
\hline Variable & Proxy or Definition & Expected sign \\
\hline GROWTHi & $\begin{array}{l}\text { Natural log of GDP per } \\
\text { capita in current US } \\
\text { dollars }\end{array}$ & \\
\hline WOR.REMi & $\begin{array}{l}\text { Workers' remittances } \\
\text { received as a \% of GDP }\end{array}$ & + \\
\hline FINDEVi & $\begin{array}{l}\text { Money and quasi money } \\
\text { (M2) as a \% of GDP }\end{array}$ & $+/-$ \\
\hline CONSUMi & $\begin{array}{l}\text { Household final } \\
\text { consumption } \\
\text { expenditure as a \% of } \\
\text { GDP }\end{array}$ & + \\
\hline SAVINGi & $\begin{array}{l}\text { Gross domestic savings } \\
\text { as a \% of GDP }\end{array}$ & $+/-$ \\
\hline CABALi & $\begin{array}{l}\text { Current account BAL or } \\
\text { balance as a \% of GDP }\end{array}$ & $-/+$ \\
\hline
\end{tabular}

\section{Empirical Results and Discussion:}

This portion of paper describes the descriptive diagnostics, outcomes of multiple regression analysis, results of diagnostic tests and then discussion on these outcomes. First of all result of descriptive diagnostics is provided in Table 2.

Table 2: Descriptive Statistics:

\begin{tabular}{|l|l|l|l|l|l|}
\hline Variable & Obs. & Mean & Std. Dev. & Min & Max \\
\hline GROWTHi & 20 & 2.753172 & 0.1381553 & 2.596968 & 3.00812 \\
\hline WORREMi & 20 & 3.416221 & 1.239567 & 1.453638 & 5.478613 \\
\hline FINDEVi & 20 & 41.73324 & 3.251651 & 36.069 & 46.37045 \\
\hline CONSUMi & 20 & 74.55008 & 3.295544 & 68.21635 & 81.9007 \\
\hline SAVINGi & 20 & 15.00785 & 2.259193 & 10.15377 & 17.61168 \\
\hline CABALi & 20 & -2.603952 & 3.684535 & -9.551735 & 5.330064 \\
\hline
\end{tabular}


The dependent variable growth has $\$ 2.75$ average GDP per capita of Pakistan for 20 years form the years 1991-2010. The standard deviation of growth is only $\$ 0.14$ which means the GDP per capita of Pakistan is deviate only $\$ 0.14$ from the average $\$ 2.75$ for sample period 1991 to 2010 . The largest value of GDP per capita is \$ 3.01 while lowest value is $\$ 2.597$. Similarly the average, standard deviation, largest and smallest value of independent and control variables is given in this table.

After descriptive diagnostics the diagnostics tests are employed in order to check the assumptions of OLS. The diagnostics tests are applied to investigates the OLS assumptions like; Multicollineartiy, Autocorrelation and Heteroskedasticity.

The diagnostic test for mulitcollinearity is multicollinearity diagnostics. The mulitcolinearity diagnostics are given in Table 3 . These statistics includes variance inflation factor (VIF) and tolerance (1/VIF). The cut-off points for VIF and tolerance is that VIF must be less than 10 and tolerance value is must be greater than 0.1 . In current study the values of VIF and tolerance are below from their cut points which suggest that there is no multicollinearity in the model.

Table 3: Multicollinearty Statistics

\begin{tabular}{|l|c|c|}
\hline Variable & Variance Inflation Factor (VIF) & Tolerance (1/VIF) \\
\hline SAVING $_{\mathbf{i}}$ & 6.05 & 0.165241 \\
\hline CONSUM $_{\mathbf{i}}$ & 5.55 & 0.180312 \\
\hline CABAL $_{\mathbf{i}}$ & 2.98 & 0.335908 \\
\hline FINDEV $_{\mathbf{i}}$ & 1.38 & 0.727252 \\
\hline WORREM $_{\mathbf{i}}$ & 1.28 & 0.778615 \\
\hline
\end{tabular}

The autocorrelation in the model is checked by looking at the Durbin-Watson Statistics. The rule of thumb is that Durbin-Watson Statistics which is in the range of 1.5 to 2.5 or near to 2 is shows the absences of autocorrelation. The Durbin-Watson Statistics in this study is 1.80 which is near to 2 , so there is no autocorrelation in this model.

The heteroskedasticity is checked through Breush Pagan test. The outcome of this test is as follows;

Breusch-Pagan / Cook-Weisberg test for heteroskedasticity

$\mathrm{H}_{0}$ : Constant variance of error term for all values of independent variables

$\mathrm{H}_{1}$ : Not have a constant variance of error term for all values of independent variables

$$
\operatorname{chi}^{2}(1)=0.80 \text { and Prob. }>\text { chi }^{2}=0.3697
$$

According to the test statistics 0.8 and p-value 0.3697 which is exceeds from 0.05 level of significance researcher fail to reject $\mathrm{H}_{0}$ that concludes that the assumption of heteroskedasticity which is constant variance of error term for all values of independent variables is not violated. As all the major assumption of OLS are analyzed through different diagnostic tests and our model fulfill all the major assumptions. The final model of OLS is provided in Table 4. 
M. M. Shafqat - A. Ahmad-S. Bano 6/2 (2014) 6-14

Table 4: Multiple Regression Analysis

\begin{tabular}{|l|c|c|c|c|}
\hline \multirow{2}{*}{ Variable } & \multicolumn{2}{|c|}{$\begin{array}{c}\text { Model with Worker } \\
\text { Remittances }\end{array}$} & \multicolumn{2}{c|}{$\begin{array}{c}\text { Model without Worker } \\
\text { Remittances }\end{array}$} \\
\cline { 2 - 5 } & Coefficients & P-Value & Coefficients & P-Value \\
\hline WORREM $_{\mathbf{i}}$ & 0.0495303 & $0.000^{* * *}$ & - & - \\
\hline FINDEV $_{\mathbf{i}}$ & -0.001049 & 0.781 & 0.0011273 & 0.857 \\
\hline CONSUM $_{\mathbf{i}}$ & 0.0433833 & $0.000^{* * *}$ & 0.047726 & $0.001 * *$ \\
\hline SAVING $_{\mathbf{i}}$ & 0.0276599 & $0.027^{*}$ & 0.0214855 & 0.265 \\
\hline CABAL $_{\mathbf{i}}$ & -0.0225714 & $0.000^{* * *}$ & -0.0187299 & $0.032^{*}$ \\
\hline CONstant & -1.080373 & 0.125 & -1.223074 & 0.286 \\
\hline F test $^{\mathbf{2}}$ & 33.39 & $0.000^{* * *}$ & 12.47 & $0.000^{* * *}$ \\
\hline $\mathbf{R}^{\mathbf{2}}$ & 0.923 & & 0.767 & \\
\hline Adjusted R & 0.895 & & 0.707 & \\
\hline
\end{tabular}

Significant at $* * * 1 \%, * * 5 \%$, and $* 10 \%$ level of significance (2-tailed).

The major outcome of this study is provided in this table of multiple regression analysis. First model which includes the worker remittances has much better result than $2^{\text {nd }}$ model which exclude worker remittances. The outcome of first model is shows that independent variable worker remittance has a positive and highly significant relationship with economic growth of Pakistan. This result is in same with the previous study that was done in Pakistan (Iqbal \& Sattar, 2005). From the four control variables only 1 control variable financial development has an insignificant and negative impact on economic growth of Pakistan. Remaining three control variables (consumption, saving and current account balance) are significant. The coefficient of determination $\mathrm{R}^{2}$ of model is 0.923 which shows that independent variables explain $92.3 \%$ variations in economic growth of Pakistan. The adjusted $\mathrm{R}^{2}$ of model is 0.895 which means that if researcher adds or removes a variable in model then its $\mathrm{R}^{2}$ is adjusted to $89.5 \%$. The $\mathrm{F}$ test statistics is 33.39 which is significant at $1 \%$ level of significance shows that model is good fit.

The second model which is run with control variables shows that two variables consumption and current account balance are significant at $1 \%$ and $5 \%$ level of significance respectively. While other two control variables financial development and saving are insignificant. Values of $R^{2}$ and adjusted $R^{2}$ of this model are 0.767 and 0.707 smaller than first model's values. The F test value is also very small as compared to first model $F$ test value only 12.47 against 33.39 . These smaller values $R^{2}$, adjusted $R^{2}$ and $F$ test value shows the contribution of worker remittances on the economic growth of Pakistan.

\section{Conclusion Policy Implementation}

This study is conduct to explore the impact of worker remittances on economic growth of Pakistan by employed the annual time series data from 1991-2010. In order to explore the relationship between worker remittances and economic growth multiple regression analysis is utilized. Different diagnostic tests are applied in order to confirm the major assumption of multiple regression analysis like multicollinearity, 
heteroskedasticity and autocorrelation. After employing all these tests multiple regression analysis is conducted which shows that worker remittances is positively and significantly contribute in the economic growth of Pakistan. So, contribution of worker remittance is the significant and most important in economic growth of Pakistan. But its productive use can helps the economy of Pakistan to maintain and improve the economic growth by investing this money into different long term and short term projects. Pakistan's Government should provide different incentives and lower down the cost of transactions to attract the overseas Pakistani emigrants that sent money through unofficial ways. This study has being focusing only on relationship between worker remittance and economic growth and the upcoming studies must investigates the relationship of worker remittances with other macroeconomic indicators like poverty reduction and entrepreneurship in Pakistan.

\section{References}

Ang, A. P. (2007). Workers' remittances and economic growth in the Philippines.

Chami, R., Fullenkamp, C., \& Jajah, S. (2003). Are immigrant remittance flows a source of capital for development? : International Monetary Fund.

Faini, R. (2002). Migration, remittances and Growth.

Gapen, M. T., Barajas, A., Chami, R., Montiel, P., \& Fullenkamp, C. (2009). Do Workers' Remittances Promote Economic Growth? IMF Working Papers.

Giuliano, P., \& Ruiz-Arranz, M. (2005). Remittances, financial development, and growth: International Monetary Fund.

Gujarati, D. N. (2003). Basic Econometrics. 4th: New York: McGraw-Hill.

International The News. (2012, 11 Januray 20112). Remittances rise 19.54pc to $\$ 6.32 b n$ in first half, International The News. Retrieved from http://images.thenews.com.pk/11-01-2012/ethenews/e-86856.htm

Iqbal, Z., \& Sattar, A. (2005). The Contribution of Workers' Remittances to Economic Growth in Pakistan: Pakistan Institute of Development Economics, c2005.

Jongwanich, J. (2007). Workers' remittances, economic growth and poverty in developing Asia and the pacific countries: United Nations Publications.

Karagoz, K. (2009). Workers' Remittances and Economic Growth: Evidence from Turkey. Journal of Yasar University, 4(13), 1891-1908.

Nsiah, C., \& Fayissa, B. (2011). Remittances and economic growth in Africa, Asia, and Latin American-Caribbean countries: a panel unit root and panel cointegration analysis. Journal of Economics and Finance, 1-18.

Pradhan, G., Upadhyay, M., \& Upadhyaya, K. (2008). Remittances and economic growth in developing countries. The European journal of development research, 20(3), 497-506.

Rahman, M., Mustafa, M., Islam, A., \& Guru-Gharana, K. K. (2006). Growth and employment empirics of Bangladesh. The Journal of Developing Areas, 99114. 
Siddique, M., Selvanathan, E. A., \& Selvanathan, S. (2010). Remittances and Economic Growth: Empirical Evidence from Bangladesh India and Sri Lanka: University of Western Australia, Business School, Economics.

Singh, R. J., Haacker, M., Lee, K., \& Le Goff, M. (2011). Determinants and macroeconomic impact of remittances in Sub-Saharan Africa. Journal of African Economies, 20(2), 312.

World Bank. (2011). Migration And Remittances Factbook 2011. Washington DC: The World Bank.

www.tradingeconomics.com - The National Accounts Committee. (2012). Pakistan GDP Growth Rate Retrieved 11 January 2012, 2012, from www.tradingeconomics.com/pakistan/gdp-growth 